DOI: $10.1515 /$ hssr -2017-0014

\title{
A Qualitative Analysis of the Global IFRS Adoption. Trustees Perspective
}

Gargalis Panagiotis*

University of Iasi, Romania

\begin{abstract}
In this article, we take a closer look at the possible effects of adopting the IAS/FIFRS standards around the globe. In order to determine what the IASB opinion regarding this impact is, we turned to the concerns of trustees. Using 3 interviews conducted with three of the trustees of IFRS on the possibility of creating a global accounting language, we realized a content analysis of the responses given. The results obtained after auto coding the responses of the trustees in NVivo, a program used in qualitative analysis, highlighted that standards adoption is an important part of the accounting process in multiple countries, national experiences being significant to the board of trustees in order to make improvements to standards at a global level.
\end{abstract}

Keywords

IAS, IFRS, Financial information, adoption impact, Europe, Asia

\section{Introduction}

The adoption of IFRS represents an example of accounting standardization among countries with different institutional frameworks and enforcement rules. As a result, the main questions addressed by researchers in the accounting field is whether the new accounting regulations have affected the quality of financial information provided by companies and truly increased the convergence of financial reporting. In

\footnotetext{
"“Alexandru Ioan Cuza" University of Iasi, Romania, Bd. Carol I nr. 11, 700506; p.gargalis@yahoo.com
} 
fact, these two aspects are the main reasons invoked by IASB - the issuer of IAS/IFRS.

The idea of issuing some international accounting standards respected by companies from every country around the globe appeared in the late 1950 s as a response to post World War II economic integration. After 20 years, the idea materialized with the forming of the International Accounting Standards Committee (1973), which became the International Accounting Standards Board (2001). As a result, the relationship between IFRS and the quality and usefulness of financial information has become a "hot topic" among financial analysts, investors, national regulation bodies, governments etc. from several countries.

\section{Defining the context of the research problem}

The impact of IFRS around the globe was addressed in multiple studies, the results of researchers varying depending on their approach, mainly the methodology used and the data set considered in the analysis.

According to IASB conceptual framework, the purpose of financial reporting consists in "providing information useful to investors, creditors, and others in order to make decisions". Because the number of users interested in financial reporting is increasingly high, IASB gives a special attention to participants in capital market and, more specifically, to investors. As a result, the research conducted on IAS/IFRS impact has focused on the link between accounting standards and share price and return in order to identify the best accounting policies.

A brief systematization of the most significant studies on this subject was done by Palea (2013) who identified 18 papers with value-relevance on IAS/IFRS adoption.

After analyzing the 18 papers included in Palea's study, we found out that most researchers had addressed some specific aspects of the topic, mainly:

1. The adoption mode, mandatory and / or voluntary;

2. The single or multi country setting;

3. The period taken into consideration was usually before and after the adoption of the IAS/IFRS; 
4. The accounting measures varied across studies, the most used being: book value of equity, earnings per share, book value of assets, book value of liabilities;

5. The methodology used included a quantitative approach of data, regression models being applied as well as different comparisons between book-to-market ratio before and after IAS/IFRS adoption.

6 . The results obtained cannot allow generalization. From the eighteen studies taken into consideration, eight showed a positive effect of IAS/IFRS, five indicated no difference after the adoption of the new regulation, three revealed mixed evidence, while two stated minor improvements in the quality of financial information after the adoption of IFRS by several countries.

In our opinion, the findings of these studies vary because the data used in the sample come from different countries and refer to multiple periods of time. Bearing these aspects in mind, we consider that the results cannot be generalized, not until an exhaustive study is conducted.

As a consequence, the mixed results from the financial literature regarding the impact of IAS/IFRS adoption on financial reporting within countriesconsistitutes the main motive of our research. While we noticed that there are significant differences between researchers' findings, we considered that a new study which takes into account a more qualitative approach can be useful in finding new opinions and connections between specific concepts of IFRS.

\section{Research aim and objectives}

Providing quality financial information, which represents the most important factor in the process of taking decisions with a low degree of uncertainty, is one of the main conditions for the development of an efficient capital market. As IFRSs adoption has focused on improving the capital markets all around the world our study focuses on determining which are the biggest concerns regarding IFRS adoption.

IASB, the issuer of IFRS, has a hierarchical structure, being ruled by a Board of trustees from several countries all around the world. They are elected to be part of the IASB in a democratic matter, their mandate within the body being for a specific period of time (3 years in the early stages of IASB and 2 years nowadays). Having this in mind we decided 
HSS, vol. VI, no. 2 (2017): 59-70

that analyzing the point of view of the trustees regarding the IFRS adoption could be a starting point for further research on the impact of IFRS adoption around the globe.

\section{Methodology}

The methodology used for conducting this study consists in several points. First, we selected the interviews in which 3 trustees expressed their vision on the impact of IFRS adoption after they were elected in this position inside IASB. The full content of the interviews is presented in the last section of the paper - Appendices. The interviews have been retrieved from the official site of IASB, http://www.ifrs.org/Aboutus/IFRS-Foundation/Oversight/Trustees/Pages/Trusteespeeches.aspx, the section dedicated to the trustees.

The method used for analyzing the content of the three interviews is the qualitative analysis in which we employed the NVivo Plussoftware.

In the first phase of the analyze we copy-pasted the content of the interviews retrieved from the official page of IASB in 3 text documents and then we introduced them as internal sources in the program. Afterwards we ran word frequencies analysis which counted all the words from the three interviews. This analysis became the starting point for coding the content of the interviews. We then used the autocodefunction in order to determine the codes which can be attributed to specific segments of the code. After determining the codes and their occurrence within the three interviews we used a matrix coding in order to analyze which codes have appeared at the same time in the three interviews analyzed. Based on that, we were able to determine if the trustees have similar opinions regarding certain subjects. In the end, we used the same co-occurrence to find out if there are linkages between the identified codes.

\section{Findings and discussion}

In order to illustrate de frequencies of the words encountered in the three analyzed interviews we used the world cloud and tree map view representation from NVivo Plus. (Figure 1 and 2) 
HSS, vol. VI, no. 2 (2017): 59-70

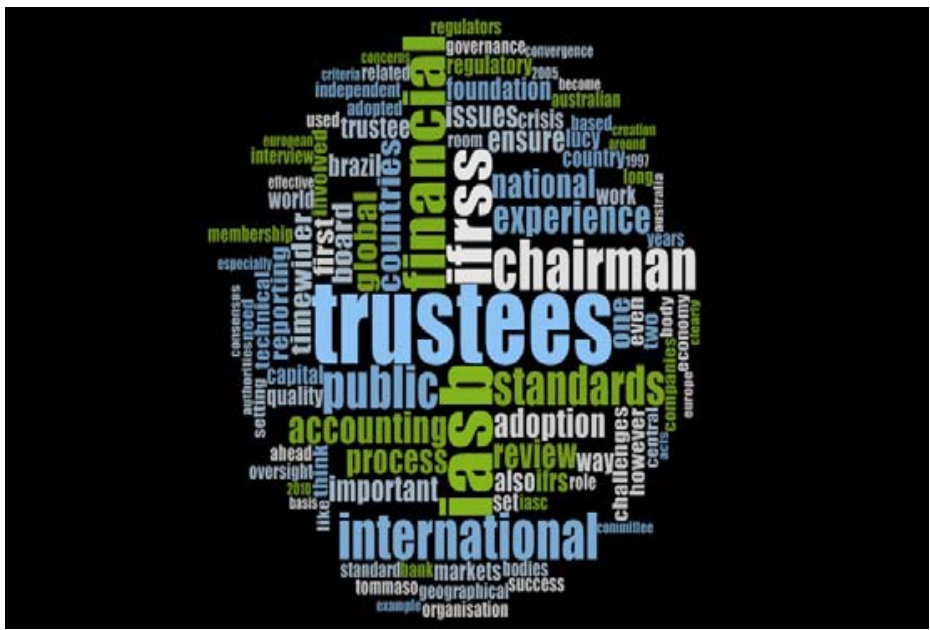

Figure 1. World cloud of the most frequent words from the three analyzed interviews. Source: author's own processing in NVivo Plus.

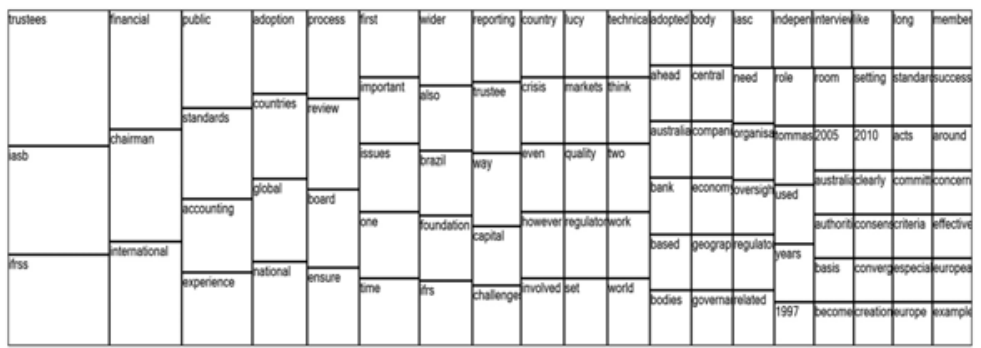

Figure 2. Tree map view of the most frequent words from the three analyzed interviews.

Source: author's own processing in NVivo Plus.

According to the summary of the frequencies on which Figure 1 and 2 are based the most frequently used words in the three interviews were: trustees (24 counts), IASB (19 counts), IFRSs (16 counts), financial (15 counts), chairman (14 counts), international (13 counts), public (12 counts), standards (11 counts), accounting (9 counts) and experience (9 counts).

Although the count of the frequencies of the words from the interviews has helped us to identify the most important concepts from the three texts, hasnot been very useful in identifying the codes which 
Gargalis Panagiotis, A Qualitative Analysis of the Global IFRS Adoption....

$$
\text { HSS, vol. VI, no. } 2 \text { (2017): 59-70 }
$$

could be extracted. To solve this matter, we resorted to the auto code function of the NVivo program which has been really helpful in identifying codes in context.

The results obtained, which are highlighted in Table 1, illustrate a total of 33 codes identified in the three interviews conducted.

\section{Table 1. Codes obtained for the most important concepts}

\begin{tabular}{|c|c|c|c|}
\hline & $\begin{array}{c}\mathrm{A}: \\
\text { Internals } \backslash \backslash 1 \mathrm{st} \\
\text { interview }\end{array}$ & $\begin{array}{c}\text { B : } \\
\text { Internals } \backslash \backslash 2 \mathrm{nd} \\
\text { interview }\end{array}$ & $\begin{array}{c}\mathrm{C}: \\
\text { Internals } \backslash \backslash 3 \mathrm{rd} \\
\text { interview }\end{array}$ \\
\hline $1:$ accounting & 1 & 1 & 1 \\
\hline $2:$ accounting standards & 0 & 1 & 0 \\
\hline $3:$ adoption & 0 & 0 & 1 \\
\hline $4:$ body & 1 & 1 & 1 \\
\hline 5 : brand name & 1 & 0 & 0 \\
\hline 6: chairman & 1 & 0 & 1 \\
\hline $7:$ channels & 1 & 0 & 0 \\
\hline $8:$ companies & 0 & 1 & 0 \\
\hline 9: effective & 1 & 0 & 1 \\
\hline 10 : financial reporting standards & 1 & 0 & 0 \\
\hline 11 : functioning & 1 & 0 & 0 \\
\hline 12 : global accounting language & 1 & 0 & 0 \\
\hline 13 : groups & 1 & 0 & 1 \\
\hline 14 : international regulator & 0 & 0 & 1 \\
\hline $15:$ issues & 1 & 1 & 1 \\
\hline $16:$ market & 1 & 1 & 1 \\
\hline $17:$ method & 0 & 1 & 0 \\
\hline 18: official & 0 & 1 & 0 \\
\hline 19: organisation & 1 & 1 & 0 \\
\hline 20 : oversight & 1 & 1 & 0 \\
\hline 21 : personalities & 1 & 0 & 0 \\
\hline $22:$ process & 1 & 1 & 1 \\
\hline 23 : public authorities & 0 & 1 & 0 \\
\hline $24:$ quality & 1 & 1 & 0 \\
\hline 25 : regulator & 1 & 1 & 1 \\
\hline 26 : representation & 1 & 0 & 0 \\
\hline 27 : responsibilities & 1 & 0 & 1 \\
\hline $28:$ roles & 0 & 1 & 0 \\
\hline 29 : set & 1 & 0 & 0 \\
\hline 30 : stability & 0 & 1 & 0 \\
\hline 31 : standards & 1 & 1 & 0 \\
\hline $32:$ term & 0 & 1 & 1 \\
\hline 33: tradition & 0 & 1 & 0 \\
\hline Total & 22 & 19 & 13 \\
\hline
\end{tabular}

Source: author's own processing in NVivo Plus 
HSS, vol. VI, no. 2 (2017): 59-70

From this total, 22 codes were identified in the interview number 1 with Pedro Malan, the Chairman of Brazil, 19 codes in interview number 2 with TommasoPadoa-Schioppa, the Chairman of Italy, and 13 codes in interview number 3 with Jeff Lucy, the Chairman of Australia.

In order to determine which codes appear at the same time in all three interviews conducted we used a co-occurrence function, the obtained results being highlighted in Table 2 .

Table 2. Codes encountered in all 3 interviews

\begin{tabular}{l|r|r|r|}
\cline { 2 - 4 } & $\begin{array}{c}\mathrm{A}: \\
\text { Internals } \backslash \backslash 1 \mathrm{~s} \\
\text { t interview }\end{array}$ & $\begin{array}{c}\mathrm{B}: \\
\text { Internals } \backslash \text { \2nd } \\
\text { interview }\end{array}$ & $\begin{array}{c}\mathrm{C}: \\
\text { Internals } \backslash \text { \r } \\
\mathrm{d} \text { interview }\end{array}$ \\
\hline $1:$ accounting & 1 & 1 & 1 \\
\hline $4:$ body & 1 & 1 & 1 \\
\hline $15:$ issues & 1 & 1 & 1 \\
\hline $16:$ market & 1 & 1 & 1 \\
\hline $22:$ process & 1 & 1 & 1 \\
\hline $25:$ regulator & 1 & 1 & 1 \\
\hline
\end{tabular}

Source: author's own processing in NVivo Plus.

According to data from Table 2 we notice that there are only 6 codes which appear at the same time in the three interviews and they address questions regarding: accounting, body (as in IFRS), issues (related to IFRS), market (regulation), process (of adopting IFRSS) and regulator (with reference to IASB as a regulator body).

Further we took a closer look to some terms where particular terms occur in content. We selected the words from those which had the biggest frequency of occurrence which were highlighted before (trustees (24 counts), IASB (19 counts), IFRSs (16 counts), financial (15 counts), chairman (14 counts), international (13 counts), public (12 counts), standards (11 counts), accounting (9 counts) and experience (9 counts)). 
HSS, vol. VI, no. 2 (2017): 59-70

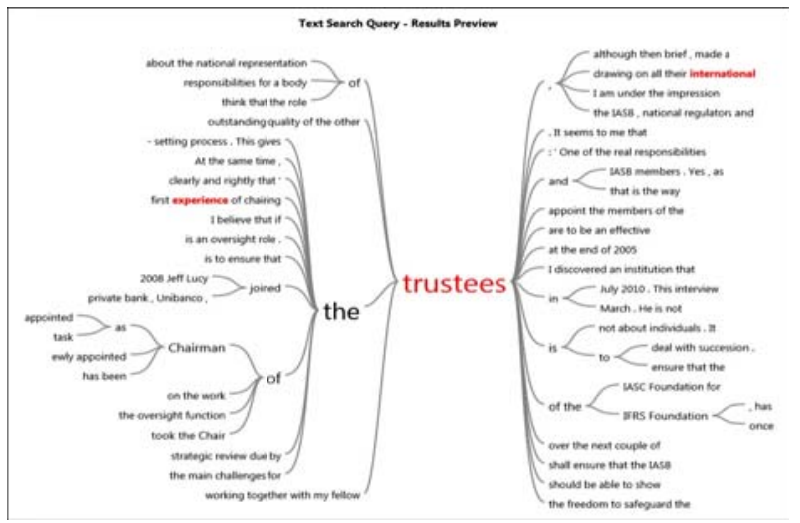

Figure 3. Occurrence of the most frequent words in context

Source: author's own processing in NVivo Plus.

The 10 words were cited in 142 places in the texts, their frequency being: 40 counts in the $1^{\text {st }}$ interview, 79 counts in the $2^{\text {nd }}$ interview and 23 counts in the $3^{\text {rd }}$ interview.

In the next figures, we illustrated the grouping of several concepts.

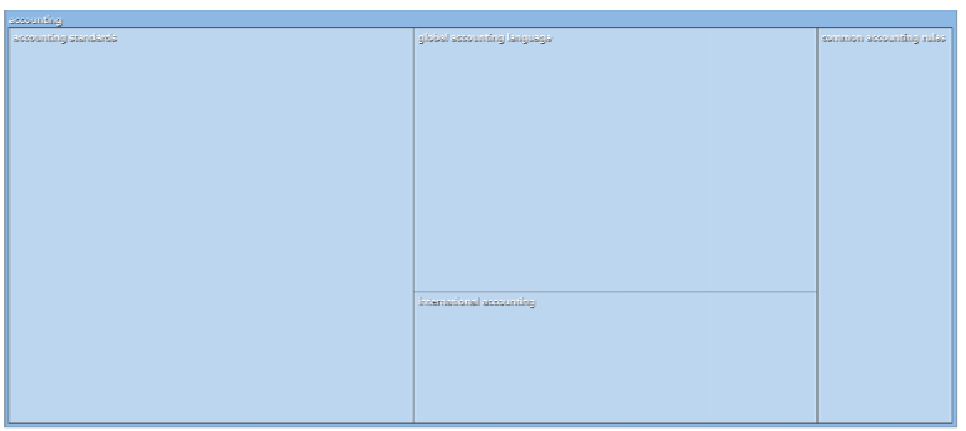

Figure 4. Nodes compared by number of coding documents for accounting Source: author's own processing in NVivo Plus.

As we can see from Figure 4, when referring to accounting, several concepts are used, such as: accounting standards, global accounting language, international accounting and common accounting rules. 


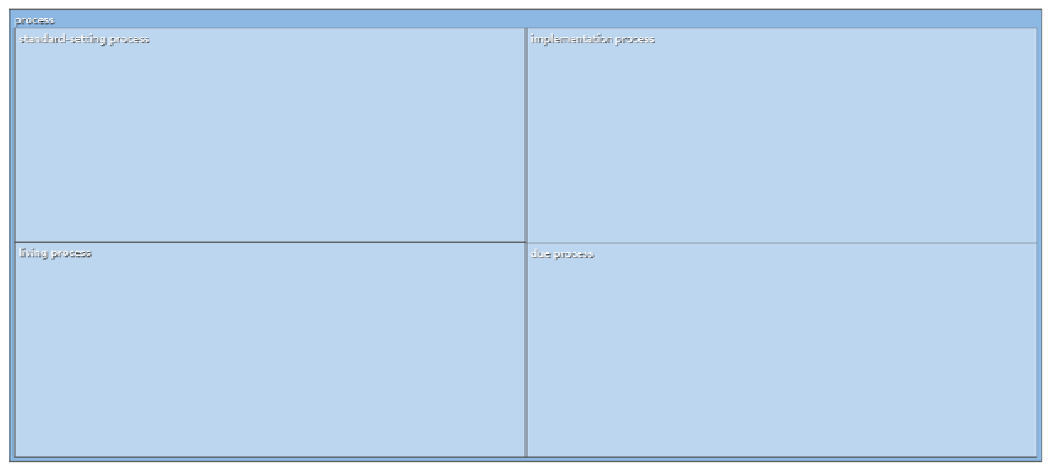

Figure 5. Nodes compared by number of coding documents for accounting Source: author's own processing in NVivo Plus.

If we refer to the code "process" we can see that we can have in mind the standard setting process, the implementation process, the due process or the living process. By applying grouping, we can find useful linkages between the codes which refer to the same issue.

The conducted analysis can be deepened on higher levels, although this wasnot the purpose of our study.From a global perspective we can say that, based on the analysis conducted, all of the 3 trustees of IFRS have expressed the same concerns regarding IFRS adoption. What does that mean? There is no place for nationalism when developing International Reporting Standards.

\section{Research limitations and further perspectives}

The research conducted has some limitations. The theme of IFRS adoption impact is very vast and we couldnot take into consideration all the issues addressed in this matter. The number of the interviews analyzed isnot that high so we cannot sustain generalization based on just three interviews with the trustee of IASB. Another limitation is due to our experience in using the NVivo Plus program in order to analyze the data. We appreciate that the use of this software has eased our work and we feel strong about using it in the future for further analysis. More than that, we believe that an improvement in our work with the program will help us in conducting more in-depth analysis in the field of IFRS adoption. 
HSS, vol. VI, no. 2 (2017): 59-70

In the end, we appreciate that our current findings and future research using qualitative analysis can be useful to formulate some hypothesis for conducting quantitative analysis in our doctoral research.

\section{References}

Agostino, M., Drago, D., \& Silipo, D. (2011). The value relevance of IFRS in the European banking industry. Review of Quantitative Finance and Accounting, 36(3), 437-457.

Armstrong, C. S., Bart, M. E., Jagolinzer, A. D., \& Riedl, E. J. (2010, January). Market Reaction to the Adoption of IFRS in Europe. The Accounting Review, 85(1), 31-61.

Ashbaugh, H. (2001). Non-US firms"accounting standard choices. Journal of Accounting and Public Policy, 20(2), 1290153.

Aubert, F., \& Grudnitski, G. (2011). The impact and importance of mandatory adoption of International financial reporting standards in Europe. Journal of International Financial Management and Accounting, 22(1), 1-26.

Barth, M. E., Beaver, W. H., \& Landsman, W. R. (2001). The relevance of the value relevance literature for financial accounting standard setting: another view. Journal of Accounting and Economics, 31(1-3), 77-104.

Barth, M., Landsman, W., \& Lang, M. (2008). International accounting standards and accounting quality. Journal of Accounting Research, 46(3), 467498.

Bartov, E., Goldberg, S., \& Kim, M. (2005). Comparative value relevance among German, U.S., and international accounting standards: A German stock market perspective. Journal of Accounting, Auditing and Finance, 20(2), 95119.

Brüggemann, U., Hitz, J. M., \& Selhorn, T. (2013). Intended and Unintended Consequences of. European Accounting Review, 22(1), 1-37.

Burgstahler, D. C., Hail, L., \& Leuz, C. (2006). The Importance of Reporting Incentives: Earnings Management in European Private and Public Firms. The Accounting Review, 81(5), 983-1016.

Christensen, H., Lee, E., \& Walker, M. (2008). Incentives or standards: What determines accounting quality changes around. AAA Financial Accounting and Reporting Section.

Comprix, J., Muller, K., \& Stanford, M. (2003). Economic Consequences from Mandatory Adoption of LASB Standards in the European. Arizona: Pennsylvania State University and Texas Christian University. 
Covrig, V., Defond, M., \& Hung, M. (2007). Home Bias, Foreign Mutual Fund Holdings, and the Voluntary Adoption of International Accounting Standards. Journal of Accounting Research, 45(1), 41-70.

Cuijpers, R., \& Buijnk, W. (2005). Voluntary adoption of non-local GAAP in the European Union: A study of determinants and consequences. European Accounting Review, 14(3), 487-524.

Daske, H., Hail, L., Leuz, C., \& Verdi, R. (2013). Adopting a Label: Heterogeneity in the Economic Consequences Around IAS/IFRS Adoptions. Journal of Accounting Research, 51(3), 495-547.

Devalle, A., Onali, E., \& Magarini, R. (2010). Assessing the Value Relevance of Accounting Data After the Introduction of IFRS in Europe. Journal of International Financial Management \& Accounting, 21(2), 85-119.

Fama, E. F. (1970). Efficient Capital Markets: A Review of Theory and Empirical Work. Papers and Proceedings of the Twenty-Eighth Annual Meeting of the American Finance Association New York, 25, pp. 383-417. New York.

Feltham, G. A., \& Ohlson, J. A. (1996). Uncertainty Resolution and the Theory of Depreciation Measurement. Journal of Accounting Research, 34(2), 209-234.

Gassen, J., \& Selhorn, T. (2006). Applying IFRS in Germany - Determinants and consequences. Betriebswirtschaftliche Forschung und Praxis(4), 365-386.

Holthausen, R. W., \& Watts, R. L. (2001). The relevance of the value-relevance literature for financial accounting standard setting. Journal of Accounting and Economics, 31(1-3), 3-75.

Hung, M., \& Subramanyam, K. (2007). Financial statement effects of adopting international accounting standards: the case of Germany. Review of Accounting Studies, 12(4), 623-656.

IASB. (2010). Retrieved from http://www.ifrs.org/Meetings/MeetingDocs/ IASB/Archive/Conceptual-Framework/Previous\%20Work/CF0901b05.pdf

Jeanjean, T., \& Stolowy, H. (2008). Do accounting standards matter? An exploratory analysis. Journal of Accounting and Public Policy, 27(6), 480-494.

Jermakowicz, E., Prather-Kinsey, J., \& Wulf, I. (2007). The Value Relevance of Accounting Income Reported by DAX-30 German Companies. Journal of International Financial Management \& Accounting, 18(3), 151-191.

Leuz, C., Nanda, D., \& Wysocki, P. (2003). Earnings management and investor protection: an international comparison. Journal of Financial Economics, 69(3), 505-527.

Ohlson, J. A. (1999). On Transitory Earnings. Review of Accounting Studies, 4(3), 145-162. 
HSS, vol. VI, no. 2 (2017): 59-70

Pae, J., Thornton, D. B., \& Welker, M. (2008). Agency Cost Reduction Associated with EU Financial Reporting Reform. Journal of International Accounting Research, 7(1), 51-76.

Pope, P. F., \& McLeavy, S. J. (2011). The European IFRS experiment: objectives,. Accounting and Business Research,, 41(3), 233-266.

Soderstrom, N. S., \& Sun, K. J. (2007). IFRS Adoption and Accounting Quality: A Review. European Accounting Review, 16(4), 675-702.

Wurgler, J. (2000). Financial markets and the allocation of capital. Journal of Financial Economics, 58(1-2), 187-214.

\section{Biographical note}

Panayiotis Gargalis is a $\mathrm{PhD}$ candidate at the "Alexandru Ioan Cuza" University of Iasi and the owner of Gargalis Construction Solution company. He graduated with honors from the University of Kentucky with a Master's degree in Business Administration and successfully completed his Bachelor's program in Civil Engineering and Master's degree in Structural Engineering. 